\title{
The House of the Dwarfs
}

\section{Author(s): David MacRitchie}

Source: The Celtic Review, Vol. 8, No. 32 (May, 1913), pp. 289-295

Stable URL: http://www.jstor.org/stable/30070253

\section{Accessed: 18-06-2016 19:59 UTC}

Your use of the JSTOR archive indicates your acceptance of the Terms \& Conditions of Use, available at

http://about.jstor.org/terms

JSTOR is a not-for-profit service that helps scholars, researchers, and students discover, use, and build upon a wide range of content in a trusted digital archive. We use information technology and tools to increase productivity and facilitate new forms of scholarship. For more information about JSTOR, please contact support@jstor.org. 


\section{THE CELTIC REVIEW}

MAY 1913

\section{THE HOUSE OF THE DWARFS}

\section{By David MacRitchie}

ThE tragic story of Darthula, otherwise Dearduil or Deirdire, and the Three Sons of Uisneach has been told many times since James Macpherson made the name of Ossian famous throughout the civilised world. The memory of Darthula'Darthula of the fair skin, whose locks were more yellow than the western gold of the summer sun '-lingered long around the shores and among the glens of Loch Etive, and only vanished with the vanishing people. It is to the late Dr. Alexander Carmichael that we owe one of the versions of this story, obtained by him as far back as 1867 from an old man in the island of Barra. Interesting although this version is in many ways, it is notable for containing one episode, peculiar, grotesque, and savage in character, which is found in other stories where Darthula does not appear. And it is to this effect. We are told how Nathos and his brothers, on their arrival in the north of Ireland from their home beside Loch Etive, were sent by Conachar, King of Ulster, to 'the house of the mercenaries' (tigh nan amhusg) for their night's lodging. They found there no fewer than fifteen score and fifteen mercenaries huddled together. 'There was not a man among them all who did not give the loud laugh on seeing these men coming home among vor. VIII. 
them.' 'What was the cause that made all of you laugh ?' asked Nathos of the commander of the mercenaries (ceannard nan amhusg). ' I will tell thee that, hero,' was the reply. ' I have never seen men of your form, and of your colour, coming home to this dwelling, and I have never seen men, a mouthful of whose flesh and a drop of whose blood I would like so'well as your own flesh and your own blood.' After this frankly cannibal confession, Nathos was moved to retort : ' I have not seen in the land of the living, nor in the company of the dead, nor among the general people of the world, those whom I would prefer to yourselves here, mercenary, to knock off your heads completely, directly, and together.' Thereupon, ' he arose in his great standing, and he seized the mercenary of biggest head and of slenderest shank, and he beat upon them up and down, on this side and on that, and before long he left not a mercenary alive. Then they cleaned the house for themselves, and raised the bright and blazing fire, and they were comfortable enough till morning.'

Of the further adventures of Nathos and his friends, as told by John MacNeill of the Bodach's Fold in Barra to Alexander Carmichael, it is needless to speak here. The main incident to be kept in view is the astonishing encounter with the 'mercenaries.' Dr. Carmichael gives no information as to his reason for interpreting amhusg as 'mercenary.' One thing certain is that his knowledge of his mother-tongue was unsurpassed, and that, consequently, 'mercenary' must be one of the equivalents of amhusg. Armstrong's definition of amhasan as 'a sentry' seems to follow the same line. But another meaning is given to amhusg by John Gregorson Campbell, a former minister of Tiree, who interprets it as 'dwarf.' It gives the title to one of the tales collected by him, $N a h$-Amhuisgean, 'The Dwarfs or Pigmies,' the sub-title being 'The Three Soldiers.' In his English translation he spells the word as 'awisk,' in order that its sound may be expressed as correctly as it may be in accordance with English phonetics. The story tells how three 
soldiers were once upon a time travelling together, and how, as they rested beside a knoll, a big red dog came to them. One of the soldiers followed the dog, which led him to a fine castle, in which there was a beautiful woman. Next day, the second soldier followed the dog to the castle, and thereafter the story is silent as to these two warriors, devoting itself to the fortunes of the remaining soldier, who, on the third day, was also conducted by the dog to the castle and the beautiful woman. 'When night came he lay down, but could not get a wink of sleep. Next morning he said to her, "What men are those making music and merriment that did not let me rest or sleep all night ?" She said to him, "I am in the same way for a year and a day; those who are at that work are the awisks." "Are you only here a year and a day ?" he asked. "I am not more," she said; "I am the daughter of a king in the kingdom of coldness. The awisks stole me away and left me here." 'The soldier's sleep was again disturbed in the same way on the following night, which so exasperated him that he made his way to the place where the awisks were engaged in their revelry. Then followed an exchange of laughs, questions, and replies, as in the case of Nathos and the 'mercenaries,' the only difference being that the awisks did not express any cannibalistic longings, but explained that the cause of their laughter was their expectation that the soldier's head would be a football to them for the rest of the night. The soldier accordingly arose in his wrath, seized the most spindleshanked of the awisks by the legs, and, using him as a warclub, routed the whole of the company. Thereafter, the king's daughter announced that she would go home, to return again with her father and her maidens and marry the soldier. In the interval, the soldier passes through some hard adventures; but at last he reaches 'the kingdom of coldness.' 'The daughter saw him, and she called out to her father, " $\mathrm{O}$ father, that is the soldier who took me from among the awisks." , And then the two were married amid great rejoicings. 
Here we have essentially the same incident as that which occurs in the story of Darthula. It is found again and again in the Gaelic legendary lore of Scotland and Ireland. The version given by J. F. Campbell of Islay in his West Highland Tales (vol. iii.) is the most graphic, and the diction is that of one John MacNair, then (1862) living at Clachaig, near Dunoon. The hero of this story is Conall Gulban, a son of the famous Neil or Nial of the Nine Hostages, ancestor of the O'Neills of Ulster. It happened that on a certain evening young Conall found himself in the realm of Lochlann, i.e. Scandinavia, near the palace of the king. In answer to his challenge of combat, he was told that 'he should get no fighting at that time of night, but he should get lodging in the house of the amhusg, where there were eighteen hundred amhusg and eighteen score. He went, and he went in, and there were none of the amhusgs within that did not grin. When he saw that they had made a grin, he himself made two. "What was the meaning of your grinning at us ?" said the amhusgs. "What was the meaning of your grinning at me?" said Conall. Said they, "Our grinning at thee meant that thy fresh royal blood will be ours to quench our thirst, and thy fresh royal flesh to polish our teeth." And said Conall, "The meaning of my grinning is that I will look out for the one with the biggest knob and slenderest shanks, and knock out the brains of the rest with that one and his brains with the knobs of the rest." ... Then he gazed at them, from one to two, and he seized on the one of the slenderest shanks and the fattest head; he drove upon the rest sliochd! slachd! till he had killed every one of them; and he had not a jot of the one with whom he was working at them but what was in his hands of the shanks.' The use of an inverted awisk as a war-club, vaguely indicated by the other reciters, is here very forcibly pictured to us.

But this was not Conall's last encounter with awisks ; for a later portion of the tale describes a similar adventure, this time in France. Here again we read of the house of the 
awisks, "the best warriors that the King of France had; and the awisks were proud and merciless to any over whom they might gain victory.' In this case, however, they had no opportunity of displaying these qualities, for Conall disposed of them as he had disposed of the 'mercenaries' of the King of Scandinavia. It is stated that just as he was about to deal with them, ' they began gnashing their teeth, making ready to spring upon him,' a peculiarly animal touch not introduced in the other accounts.

It would be tedious to go into all the points of difference and resemblance between these versions and others that have been recorded. In 1889-90 the Rev. James MacDougall, Duror, obtained a variant of the 'Lad of the Skin Coverings' (Gille nan Cochla-Craicinn) from a native of Ardnamurchan, Alexander Cameron, who had learned it from a certain Donald M'Phie and other old men whom he had known in his boyhood. In Cameron's story the hero is victorious over 'eighteen score and eight avasks' in the same grotesque way as in the other instances, and the combat is preceded by the same absurd exchange of laughs and questions. An Irish version, preserved in Larminie's West Irish Folk-Tales (London, 1893, p. 77), renders the Gaelic word amhusg or amhas into 'owas,' as the best equivalent according to English phonetics. In this tale, the name of the hero is Ceudach, or otherwise Ceudach mac Righ nan Collach, or son of the King of the Colla men. This title was borne by the 'Lad of the Skin Coverings,' according to Gregorson Campbell, which brings us back again to his tale of the Three Soldiers. Thus, Nathos, son of Uisneach, Conall Gulban, son of Nial of the Nine Hostages, Ceudach, son of the King of Coll, and the unnamed soldier of the Tiree version, each figure as the destroyer of many hundred awisks, whose brains were battered in by means of one of their number, swung about by his shanks, gripped by the hands of the hero.

What is to be made of this savage and fantastic story? The Rev. James MacDougall, commenting upon his Ardna- 
murchan version, explains it thus:- 'This tale is mythological from one end to the other. I believe that the Lad of the Skin Coverings [who is yellow-haired] is the golden dawn with its fleecy clouds. Finn [here associated with him] is the Sun, and as such the King of Light. His journey to the place of the Queen of Roy [Red] is the Sun's daily course from east to west. The latter is accompanied on its way by the Dawn, which remains invisible until it comes forth in the evening as Twilight. Both then enter the golden or silver portals of the west. The struggle between the Dawn as Twilight and the clouds of darkness-represented by the Avasks-now begins, and terminates afterwards in favour of the former - $a$ result supposed to be rendered evident enough by "the heaps" or masses of clouds piled outside the portals of night, or just above the western horizon.' It ought to be explained that in this Ardnamurchan story the hero and Finn 'put the dead bodies out, and made three heaps of them at the door.'

This is one explanation. Campbell of Islay offers another, of a very different kind. 'Perhaps these may have something to do with the Baresarks of the old Norsemen, who were " public pests," great warriors, half crazy, enormously strong, subject to fits of ungovernable fury, occasionally employed by saner men, and put to death when done with. I suspect,' he concludes, 'this guard-house of savage warriors has a foundation in fact.' If an Eastern origin of the story could be admitted, this interpretation would receive support from a reference made by Sir Bertram Windle, especially if it be kept in view that Gregorson Campbell translates 'awisks' as 'dwarfs or pygmies.' In the course of an extensive survey of dwarf races, Sir Bertram Windle quotes the Greek historian, Ctesias, to the effect that 'Middle India has black men, who are called pygmies. Of these pygmies, the king of the Indians has three thousand in his train; for they are very skilful archers.' 'There seem to have been near Lake Zerrah, in Persia,' continues the Irish scholar, 'Negrito [i.e. black dwarf] tribes who are probably aboriginal, 
and may have formed the historic black guard of the ancient kings of Susiana.' There is thus evidence of dwarf tribes employed by Oriental kings as mercenary troops, to whom the Gaelic name of amhusg might be fitly applied, whether we accept the late Dr. Carmichael's interpretation of the word, or that given by Gregorson Campbell. It might be argued, therefore, that this Gaelic tale had its origin in Asia, and was subsequently carried westward and made to fit in with places and people chiefly associated with the west of Scotland and the north-east of Ireland.

\section{CREDE'S LAMENT FOR CAEL}

\section{JohN M. Paterson}

A woeful note and, oh! a woeful note

Pours thro' Drumqueen from the sad thrush's throat, And dismal, dismal is the doleful lay

Wherewith the blackbird saddens Hetherlee.

A doleful sound and, oh! a doleful sound, Comes from the deer in Drumdaleish and round,

With lifted heads thro' lonely paths they go

For in Drumsheelin lies the stricken doe.

My sorrow's sore and, oh ! my sorrow's sore For Cael the well beloved, my Cael's no more.

As bell the stag in throes of deadly pain

So sorrow I for my beloved slain.

Cold lies the form so late my woman's pride;

No more I'll nestle warmly to his side

For death's dark wave has swept his life away.

I sat in sorrow thro' the livelong day.

A dismal roar, with what a dismal roar The sullen surf comes surging to the shore,

Beating the polished rock with mournful boom!

So frets my soul at Cael's untimely doom. 